\title{
Satisfied with Quality Yet Wants to Switch: Case of 'Satiated Customer' in Telecom Services
}

\author{
Akshaya Kumar Sahoo \\ Research Scholar, SOA University, Bhubaneswar, India, akshayasahoo2004@gmail.com \\ Brajaballav Kar \\ Associate Professor, KIIT University, Bhubaneswar, India, brajkar@gmail.com \\ Srikanta Charana Das
}

Associate Professor, KIIT University, Bhubaneswar, India, srikant68@gmail.com

\section{Doi:10.5901/mjss.2015.v6n6s4p192}

\section{Abstract}

\begin{abstract}
Telecom Service Industry in India is going through a phase of high growth, excessive competition, continual lowering of tariffs and rapid change of technology. Policies are still evolving and causing substantial change in the competitive landscape. Telecom Services have become more commoditized; it is easy to replicate. The market can be compared to a red sea, and it does not give sustainable competitive advantage. Customer retention and addition of new customers becomes very crucial for the profitability and survival. The research takes the responses of 803 customers of different telecom service providers and analyses their response with respect to quality perception, duration of use and switch intention. The responses are further correlated to the demographics of the sample to generate understanding about their behavior. The research finds that there is a need to relook at the relatedness of 'loyalty' and 'service quality' concepts in telecom sector, precisely when customers are simultaneously using multiple services from multiple service providers. The data analysis indicates that long term customers with higher level of satisfaction and higher income are more likely to have greater intention to switch.
\end{abstract}

Keywords: Satiated Customer, Telecom Service, Quality.

\section{Introduction}

\subsection{Telecom Industry Growth in India}

India's tele-density has gone up from 4 percent in March 2001 to 75.23 percent by March 2014, indicating the total mobile subscriber base of 932 million (Industry report 2014). In one year the land line subscriber's connectivity has declined from 30.21 million to 28.59 million by March 2014. Wireless broadband connections (>=512 kbps) have a subscriber base of about 43.2 million. The growth is further fuelled due to tariff reduction and decline in handset costs. Consumption of data services is growing at an exponential pace. Intense competition has made sure that customers get prompt service and at low tariff. Still there is low penetration in rural and semi-urban areas, thus a potential for further growth is indicated. The industry is characterized by 'higher capital investments', 'more number of players', 'Country-wide network requirement', 'rapid change of technology', 'license fee for covered regions' and 'low tariffs'. These factors indicate commoditization of telecom services and low bargaining power of service providers (Equity master report 2014).

Technological advancement also has played its role in acceptability. Technology has given more functionality through Smart phones and Phonotabs. Indian customers have been able to keep the same number but change the service provider (Mobile Number portability). Growth of infrastructure capability has also helped customers to have better internet speed, and through recent policy changes, even free internet access through the digital India smart city programs. Telecom services are no longer used for basic person-to-person communication only; it is becoming richer, robust and multi-faceted.

How do customers react to such changes? How do they perceive the value in a dynamic context? What does it mean for customer loyalty? The following section discusses extant literature on these issues. 


\section{Literature Review}

\subsection{Service Quality}

Focus on service quality contributes to the reduction of cost, increase of profitability and loyalty from customer (Cronin and Taylor, 1992). Customer loyalty is derived from the customer's perception and feelings regarding the quality, resulting in her satisfaction (Bertrand, 1989). Positive relationship of 'service quality' with 'customer satisfaction has been indicated by many researches (Cronin and Taylor, 1992; Danaher and Mattsson, 1994; Kim et al., 2004). Similarly 'service quality' is also positively associated with 'customer preference' (Ranaweera and Neely, 2003); "profitability" (Fornell, 1992; Danaher and Rust, 1996), and 'competitiveness, (Rapert and Wren, 1998). To an extreme, it has been argued that customer satisfaction should lead to 'customer delight' (Oliver, 1999) and deliver superior value (Parasuraman \& Grewal, 2000) by means of quality of the product or services. 'Customer delight' and 'superior value' are argued to be two means to attain customer loyalty. Retaining of existing customers is also associated with customer satisfaction (Brown \& Gulycz, 2001). Customer's perception of quality or value gets influenced by switching cost (Fornell, 1992; Lee et al., 2001; Oliver, 1999; Neal, 1999; Woodruff, 1997). Perceived value as comprehensive assessment of the benefits that the customer gets (Zeithaml, 1988), includes the total price paid. So the perception of value takes into account the 'perceived benefit' and 'total sacrifice' (Monroe, 1991). This indicates that depending on context, a service may be evaluated by same customers differently. While forming the perception of service quality customers integrate their experiences (Bolton and Drew, 1991). The overall perspective takes into account of 'previous expectation', 'current performance' and any 'disconfirmation experience'. Past experience also influences the perception of service quality (O'Neill and Palmer, 2003). These factors indicate that "Service quality is by nature a subjective concept" (Rust and Oliver, 1994). One more dimension of service quality is indicated to be 'differentiated service', if a service can be differentiated from existing ones, then it would influence the quality perception (Sahoo, Kar and Das, 2015).

Does the switching intention is because of quality per-se of there are other factors to it? The following section discusses about literature pertaining to switching intention.

\subsection{Switch Intention}

It could be assumed that in the presence of a sense of satisfaction, there would higher loyalty and lower intention to switch to a different service provider. How does the assumption hold in a highly competitive service industry? The act of switching service providers could be due to the influence of past behavior, wherein customer switches due to habit only. If the context is similar and if the behavior is recurring; then the future response could be automatic due to habit but if the context is different or the behavior is not well learned, then the decision making becomes conscious (Ouellette and Wood, 1998; Danner et al., 2008). Past behavior in such case influences intent, which guides the behavior. If intentions are stable, past behavior does not relate to subsequent action (Sheeran, et al., 1999), but if intentions are unstable, past behavior is close predictor of future action. So on what factors the intention to switch would correlate more in case of telecom industry?

Relationship between customer satisfaction and loyalty is not without debate. Questions have been raised about the relationship (Mittal and Lassar, 1998) and research indicates that as much as fifty percent of the satisfied customers switch. The explanation being the extension of quality dimensions by 'technical quality' and 'functional quality'. The satisfaction from technical quality is of low contact, whereas satisfaction from functional quality is of high contact; high contact satisfaction may indicate a lower switch intention.

There could be intrinsic and extrinsic incentives to switch brands (Mazursky et al, 1987). Extrinsic motivations (marketing promotions) induced customers to switch inspite of high level of satisfaction, but it may not be significant for repurchase intention. Intrinsic incentives (desire to try a new brand) could contribute to lesser degree for a switch intention.

In a study of bank switching behaviour (Chakravartya, et al., 2004) indicated that customer's feeling of the bank's responsiveness, empathy and reliability to the needs correlates significantly negatively with intention to switch banks. Thus the strength of relationship limits the switch intention.

In one of the research (Keaveney, 1995) 800 critical behaviors of service firms that caused customers to switch services were identified. In the context of huge customer growth and frequently changing marketing and services mix, the customer would perceive a 'Churn' which in turn will impact the switch intention (Keaveney and Parthasarathy, 2001).

Research in a different context (Ewing, 2000) indicates that expectation to repurchase and recommend the brand vis a vis from the same or different retailer. The research indicates that the brand/consumer relationship explains the 
loyalty better than retail/consumer relationship. The willingness to recommend is not necessarily influenced by past behaviour, higher the purchase intention, higher would be willingness to recommend the brand.

There is also contrary evidence (Morwitz, 1997) to the proposition that customers can predict their own future behaviour.

The discussion above indicates the necessity of studying the customer behaviour in a service industry which is dynamic due to number of competitors, change of policies, higher growth, higher degree of replicability, and ever expanding technical capability to give additional services over a base service.

\subsection{Research gap and objectives}

As discussed in the literature review, many studies have indicated the relationship between service quality, customer satisfaction and retention. Quality is related to the need satisfying capability, thus it could be argued that it is the degree to which customer satisfaction is met. However, in many technical products or services, customer does not dictate the need. On the contrary, innovative products and services are presented before the customers, from which customer can experiment, choose, use and be satisfied with the experience. There was no expressed need to which the product or service caters to. In this case, customer is exposed to multiple services at a much faster rate, which could influence the 'switch intention'. Many of the technical features may not even be used by many of the customers, so, in a sense, it may create surfeit of features to satiate the customer. Customer may be over-satisfied with the features and could be prone to switching. It could also be argued that customers want to change because of past habit, to experiment. This research tries to address this aspect.

Telecom services present such a scenario wherein the services are not generated because of explicit customer needs. Hardware, software, internet and other related services available through mobile devices form a service bunch. Unlike other services the customer churn is also quite high in telecom services. This research tries to find the factors on which the 'switch intention' depends.

\section{Methodology}

The methodology was based on questionnaire survey to understand the perception of customers about the 'quality of services', 'past switch behavior' and their 'switch intention' The research was planned and conducted for the state of Odisha, India. Responses were collected through a questionnaire. The questionnaire had demographic data like gender, age, occupation, income, education, and location of stay. Second part of the questionnaire sought responses for questions to the name of the service providers uses, most of used service providers and if the service is pre paid or post paid. Third part of the questionnaire had Likert scale based question like, 'To what extent the service has met your expectation', 'How often did you change service provider in the past 2 years', 'How long you have used the current service provider' and 'Do you have intention of switching in future'.

The responses were tabulated and relevant analysis were carried out in SPSS

\section{Data Analysis}

\subsection{Demography of the sample}

Age: According to age the distribution of the respondents was as follows: 6.6 percent of the respondents was below 20 years, 32.6 percent was between 20-29 years, 29.1 percent was between 30-39 years, 19.9 percent was between 40- 49 years and 11.7 percent was 50 years and above.

Occupation: According occupation, 15.2 percent was government employees, private sector employees constituted 33.4 percent, student constituted 13.9 percent, 12.6 percent was businessperson, housewife was 10.3 percent, 1.2 percent were farmers, 13.3 percent belonged to "others" categories.

Income: 18.8 percent of the respondents had income below rupees 10000, 39.2 percent had income between rupees 10000 and 25000, 27.5 percent had income between rupees 25000 and 50000 and 14.4 percent of the respondents had income above rupees 50000 per month.

Education: Eighteen percent of the respondents have within 10 years of education (matriculate), 10.7 percent had 12 years of education (intermediate), 3.9 percent were diploma holder, about 39 percent were graduates, 18 percent were post graduates and 10.3 percent had professional education.

Stay: According to location of stay, respondents were classified into rural, semi urban and urban area with distributions as 17.2, 31.3 and 51.6 percent respectively. 


\subsection{Existing usage pattern of network/ Service provider}

In the questionnaire, there were two questions asked as "Which mobile telecom network (s) do you have"? and the other question was "which of the service provider network is most often used"? Respondents indicated multiple choices of different telecom service providers in case of the first question, whereas they would indicate only one provider for most often used question. Responses have been tabulated below.

Table 1: Service Providers, how many have and how often used.

\begin{tabular}{|c|l|c|c|c|c|c|}
\hline SI\# & Service Providers & \multicolumn{2}{|c|}{ Most often used } & \multicolumn{2}{c|}{ Have the service } & Percent Used \\
\hline 1 & Bsnl, & 373 & $46 \%$ & 411 & $51 \%$ & $91 \%$ \\
\hline 2 & Airtel & 107 & $13 \%$ & 165 & $21 \%$ & $65 \%$ \\
\hline 3 & Aircel & 66 & $8 \%$ & 121 & $15 \%$ & $55 \%$ \\
\hline 4 & Reliance & 97 & $12 \%$ & 185 & $23 \%$ & $52 \%$ \\
\hline 5 & Vodafone & 63 & $8 \%$ & 117 & $15 \%$ & $54 \%$ \\
\hline 6 & Tata Docomo & 53 & $7 \%$ & 97 & $12 \%$ & $55 \%$ \\
\hline 7 & Idea & 39 & $5 \%$ & 66 & $8 \%$ & $59 \%$ \\
\hline 8 & Tata Indicom & 5 & $1 \%$ & 16 & $2 \%$ & $31 \%$ \\
\hline & & 803 & $100 \%$ & 1178 & $147 \%$ & \\
\hline
\end{tabular}

The percent used column have been calculated Usage (Most often used / Have the service)

The table indicates that BSNL has the highest penetration of 51 percent (411 indicate of having Bsnl out of 803). Of the persons having Bsnl service (412) 91 percent (373) use the service most often (So Total Service $=\%$ Penetration * $\%$ Used).

Since individual customers could have services from different service providers, the responses of all such providers for a single individual were added up. In effect it means, total of 1178 services are provided to 803 customers. The ratio would indicate the average level of redundancy individual customer has, and in this case it would be 47 percent.

\subsection{Perceived quality}

Service Compared to Desired level: only 2.2 percent of the respondents indicate that the service is much worse compared to the desired level, 7.6 percent think it worse, 36.4 finds it at the desired level, 53.8 percent find it either better or much better. Overall it indicates that customers find the service quality as per their expectation.

\subsection{Duration of Service Usage}

The respondents indicate the following duration of service usage from their service providers: 4.5 percent have been using the same service provider for less than a year, 13 percent between 1 to 2 years, 15.3 percent between 2-3, 11.3 percent between 3-4 years, 13.4 percent between $4-5$ and 42.5 percent have been using the same service provider for more than 5 years.

\subsection{Past switch Information}

Respondents indicated about their past switch information behavior as follows: 14.6 percent did not go for a switch within last 2 years, 1.9 percent switched once, 5.5 percent switched two times, 13.1 switched three times but surprisingly 65 percent of the respondents indicated that they switched more than 3 times during past 2 years. However it needs to be pointed that the reason for switch was not asked specifically in the questionnaire.

\subsection{Intention to Switch}

When the intention to switch was asked, 18.8 percent indicated that they definitely would like to switch. 11.8 percent indicated it as somewhat yes. 48.1 percent indicates as somewhat no or definitely no. If the neutral response (21.3 percent) is taken off then $39 \%$ would indicate the intention to switch and 61 percent don't indicate any switch intention.

The basic percentage analysis above indicates few interesting observations. Fifty four percent of the users find the 
service better compared to their expectation, 42.5 percent have been using the same service provider for more than 5 years, yet 65 percent indicate they switched more than three times and 39 percent would like to switch their telecom service provider. It sounds paradoxical. However if the distribution with respect to number of service providers per customer is considered then it is found that; $566(70.5 \%)$ use one, 148 (18.4\%) use two, $55(6.8 \%)$ use three, 26 (3.2\%) use four and 1 percent use more than four service providers. So in a sense about 30 percent who are having more than one service provider would have lower switching cost (higher redundancy and lower time). The lower redundancy available to 70 percent single service provider customers may explain a higher usage period for 42.5 percent for more than 5 years.

\subsection{Bi-variate Analysis}

In the following section the relationship has been explored with various factors with three major areas like 'prior switching behavior', 'existing quality perception' and 'future switching intention'

\subsection{Gender and Quality Perception}

The responses to the question "to what extent have your mobile network services have met your expectation" were analyzed for gender differences. The association test does not indicate (Pearson $x^{2} 7.486, \mathrm{df}=4$, significance $=.112$ ) any significant association.

\subsection{Gender and past change}

The generic assumption of female being more loyal than male customers has been clarified to be context dependent (Valentyna, et al., 2009). Female customers have been reported to be more loyal to the individual service provider than a group. Similar is the case of loyalty to a person rather than company in an employment scenario. The research (Valentyna, et al., 2009) suggests that there are specific objects of loyalty, which could be the product, company or an individual.

In this case, the behavior of changing service providers for last two years was analysed across gender and tabulated as below.

Table 2: Gender and how many times the service provider is changed in past two years.

\begin{tabular}{|c|c|c|c|c|c|c|c|}
\hline & & \multicolumn{5}{|c|}{ Changed service provider in past 2 years } & Total \\
\hline & & Never & Once & 2 times & 3 times & $>3$ & \\
\hline \multirow{3}{*}{ Gender } & Female & 34 & 3 & 8 & 22 & 114 & 181 \\
\hline & Male & 83 & 12 & 36 & 83 & 408 & 622 \\
\hline & Total & 117 & 15 & 44 & 105 & 522 & 803 \\
\hline
\end{tabular}

The table indicates that 18.78 percent of the women and 13.34 percent of men never changed their service provider in the past two years. However, about 63 percent women and 66 percent of the men changed their service provider more than 3 times in the past 2 years. The test of association (Pearson $X^{2}$ value $=3.681, \mathrm{df}=4$, significance $=.451$ ) however indicates that the association between changing of service providers and gender is insignificant.

Similar cross tabulation was done for gender and switching intent and the data is presented as below.

Table 3: Gender and Switch Intent.

\begin{tabular}{|c|c|c|c|c|c|c|c|}
\hline & & Definitely Yes & Somewhat Yes & Not Sure & Somewhat No & Definitely No & Total \\
\hline Gender & Female & 23 & 22 & 38 & 37 & 61 & 181 \\
\hline & Male & 128 & 73 & 133 & 130 & 158 & 622 \\
\hline & Total & 151 & 95 & 171 & 167 & 219 & 803 \\
\hline
\end{tabular}

Thirteen percent of the females and 21 percent males indicated to definitely switch, where as thirty four percent of females and 25 percent of males have indicated definitely no to the switch intention. It may indicate a stronger loyalty of women consumers in percentage terms. However, the association test (Pearson $X^{2}=8.206, \mathrm{df}=4$, significance $=.084$ ) does not indicate a significant relationship of gender and switch intent. 


\subsection{Age and Satisfaction}

To investigate if age has some association with being meeting of expectation, $x^{2}$ correlation analysis was carried out. Data was regrouped to meet the $x^{2}$ test condition of minimum value in a cell. The test indicates (Pearson $x^{2}=28.453, \mathrm{df}=$ 6 and significance $=.000)$ that there exist a significant association $(p<.01)$ with the service provider being able to meet expectation and age. The subsequent correlation test indicates that (Pearson's $R=-.125$, significance $=.000$ ) there is a significant negative correlation between age and meeting the expectation. This could indicate that the respondents perceive a lower "expectation met" with increase in the age group. It could be contrary to the expectation that with increase in age, the expectation from the service provider goes down.

\subsection{Age and switch Intent}

Similar test for association was carried out between Age and switch intent.

Table 4: Age and Switch Intent.

\begin{tabular}{|c|c|c|c|c|c|c|c|}
\hline & & Definitely Yes & Somewhat Yes & Not Sure & Somewhat No & Definitely No & Total \\
\hline Age & $<20$ & 10 & 10 & 14 & 7 & 12 & 53 \\
\hline & $20-29$ & 56 & 33 & 42 & 69 & 62 & 262 \\
\hline & $30-39$ & 32 & 29 & 63 & 45 & 65 & 234 \\
\hline & $40-49$ & 33 & 14 & 31 & 32 & 50 & 160 \\
\hline & $>50$ & 20 & 9 & 21 & 14 & 30 & 94 \\
\hline Total & & 151 & 95 & 171 & 167 & 219 & 803 \\
\hline
\end{tabular}

The test of association (Pearson $\mathrm{x} 2=27.342 \mathrm{df}=16$ Significance $=.038$ ) indicates a significant association $(\mathrm{p}<.05)$. However the correlation (Pearson's $R=.044$, significance $=.215$ ) does not indicate a significant correlation $(p>.05)$.

\subsection{Age and Past change}

To test the responses related to age and their past change behavior the test of association indicates (Pearson $X^{2}=$ 23.298, $d f=12$, significance $=.025)$ an association between the two $(p<.05)$. The responses in this case were clubbed to comply with the test requirement of values in each cell. The past change and age however, does not indicate a significant correlation (Pearson's $\mathrm{R}=.040$, significance $=.253$ ).

\subsection{Stay and Switch Intent}

Telecom services have definite differences in their services in rural, semi-urban and urban areas. The per customer revenue being different the capital investment for services would be different and thus the service experience is expected to be different among these areas. It could also be argued that status of awareness being different, such difference of services may be acceptable by the customers in different areas. In few of the cases such issues are identified with digital divide.

Table 5: Stay and Switch Intent.

\begin{tabular}{|c|c|c|c|c|c|c|c|}
\hline & & Definitely Yes & Somewhat Yes & Not Sure & Somewhat No & Definitely No & Total \\
\hline Stay & Rural & 42 & 21 & 24 & 26 & 25 & 138 \\
\hline & Semi-Urban & 36 & 23 & 63 & 75 & 54 & 251 \\
\hline & Urban & 73 & 51 & 84 & 66 & 140 & 414 \\
\hline Total & & 151 & 95 & 171 & 167 & 219 & 803 \\
\hline
\end{tabular}

Stay and switching intent indicates a significant association (Pearson $X^{2}=47.406, \mathrm{df}=8$, significance $=.000$ ) and subsequent coefficient of correlation calculation also indicates a significant but low correlation (Pearson's R $=.121$, significance $=.001$ )

Stay and Past Change: Does the place of stay and number of times the customers have changed service provider 
has any relationship? The association test indicates (Pearson $X^{2}=16.928, \mathrm{df}=8$ significance $\left.=.031\right)$ a significant $(p<.05)$ relationship, however the coefficient of correlation was not found to be significant (Pearson' $R=.008$, significance $=.829$ )

Stay and meeting expectation: When the association between the place of stay and the degree to which customer expectation has been met is tested (Pearson $X^{2}=21.079, \mathrm{df}=8$, significance $=.007$ ), it indicates a significant association.

\subsection{Income and Past change}

For most of the customer's the telecom service provider charges form a very insignificant part of the income. In India, the competitive pressure as well as huge number of call plans makes sure that the service provider's charges remain low. Could it imply that the customers would be indifferent with respect to expectations from the service providers?

Income and past 'change of telecom service providers' indicate (Pearson $\chi^{2}=39.308, \mathrm{df}=9$, significance $=.000$ ) a significant association $(p<.01)$ and the coefficient of correlation indicates a weak positive correlation (Pearson's R $=.141$, significance $=.000)$.

\subsection{Income and degree of expectation met}

It was assumed that individual's income and the degree to which the expectation has been met is independent. Seemingly both are independent however there is a possibility that the higher level of income may influence the expectation as well. If the expectation is higher then, there will be low degree to which the expectation would be met. This in a sense could indicate a negative relationship.

The responses in this case was analysed for association and it indicated a significant association (Pearson $X^{2}=$ 34.056, $\mathrm{df}=9$, significance $=.000$ ). The subsequent correlation analysis resulted in Pearson's $\mathrm{R}=-.053$ with significance $=.133$. This indicates an association and the negative correlation is not significant $(p>.05)$.

\subsection{Income and Switch Intent}

Individual's income and switching of telecome service provider was hypothesized to be independent, the following cross tab was obtained.

Table 6: Income and Switch Intent.

\begin{tabular}{|c|c|c|c|c|c|c|c|}
\hline & & Definitely Yes & Somewhat Yes & Not Sure & Somewhat No & Definitely No & Total \\
\hline Income & $<$ Rs 10K & 44 & 25 & 27 & 21 & 34 & 151 \\
\hline & $10-25 \mathrm{~K}$ & 59 & 36 & 73 & 77 & 70 & 315 \\
\hline & $25-50 \mathrm{~K}$ & 24 & 25 & 48 & 54 & 70 & 221 \\
\hline & $>50 \mathrm{~K}$ & 24 & 9 & 23 & 15 & 45 & 116 \\
\hline & Total & 151 & 95 & 171 & 167 & 219 & 803 \\
\hline
\end{tabular}

The association test (Pearson $X^{2}=44.001, d f=12$, significance $\left.=.000\right)$ indicated a significant association $(p<.01)$. The Pearson's coefficient of correlation was calculated to be.147 with a significance of .000 . Thus it indicates that there would be a higher proclivity to switch as the level of income rises.

\subsection{Education and Expectation met}

Individual's education and expectation being met by the service provider was hypothesized to be independent. The test of association (Pearson $X^{2}=15.838, \mathrm{df}=15$, significance $=.393$ ) indicated that education is not significantly associated with expectations being met. Though it could be assumed that education influence the demand for service and pushes up expection, it was not found in the current data.

\subsection{Education and past change}

If education and expectations are independent then, it could be assumed that education and the respondents past behavior also should be independent of each other. However the association test indicates that (Pearson $X^{2}=22.192$, df 
$=8$, significance $=.005)$ the education and past behavior of changing service providers is associated. The Spearman Correlation was found to be $=.082$ with a significance of $.020(p<.05)$

\subsection{Education and Switching Intent}

Response to highest education was transformed to satisfy the constraint of cell value in Chi-Square test. Education and switching intent were assumed to be independent. The association test indicated (Pearson $X^{2}=36.813$, $\mathrm{df}=8$, significance $=.000$ ) that both have a significant relationship. Thus the null hypothesis was rejected.

\subsection{How Long used and switch intention}

It is generally accepted that a brand loyal customer uses the brand for a long time. Such a customer has low intrinsic motivation to switch. The questionnaire asked about the length of their service usage from a service provider, and at the same time it asked about the future switch intention. The data was tabulated after necessary transposing for Chi-square test condition.

Table 7: Cross tab 'Using for how long' and 'Intent to switch'.

\begin{tabular}{|c|c|c|c|c|c|c|}
\hline & & 1 & 2 & 3 & 4 & Total \\
\hline \multirow{3}{*}{ How long used } & 1 & 15 & 6 & 9 & 6 & 36 \\
\cline { 2 - 7 } & 2 & 20 & 25 & 22 & 37 & 104 \\
\cline { 2 - 7 } & 3 & 14 & 21 & 23 & 65 & 123 \\
\cline { 2 - 7 } & 4 & 102 & 43 & 117 & 278 & 540 \\
\hline & Total & 151 & 95 & 171 & 386 & 803 \\
\hline
\end{tabular}

The test of association indicated (Pearson $X^{2}=50.430, \mathrm{df}=9$, significance $=.000$ ) a significant association and subsequent test for correlation coefficient (Pearson's $R=.151$, significance $=.000$ ). The result indicates that longer the customer uses a service provider higher would be the motive to switch.

\section{Regression Analysis}

Regression analysis was carried out on the responses with predictors as number of switches in the past two years, location of stay, pre-paid or post paid, the degree to which the service has met expectation, for how long the service was used, occupation, income, education, and age. Gender being a dichotomous variable, was not considered for regression analysis.

Table 8: Model Summary.

\begin{tabular}{|c|c|c|c|c|}
\hline Model & $\mathrm{R}$ & $\mathrm{R}$ Square & Adjusted R Square & Std. Error of the Estimate \\
\hline 1 & .347 & .120 & .110 & 1.368 \\
\hline
\end{tabular}

The $\mathrm{R}$ square value in this case indicates that $12 \%$ of the variances are explained by these factors (number of switches in the past, location of stay, prepaid or post paid, the degree to which the services met expectation, how long the services is used, occupation, income, education and age).

Table 9: Analysis of Variance.

\begin{tabular}{|l|l|c|c|c|c|c|}
\hline \multicolumn{2}{|l|}{ Model } & Sum of Squares & df & Mean Square & $\mathrm{F}$ & Sig. \\
\hline \multirow{2}{*}{1} & Regression & 203.129 & 9 & 22.570 & 12.053 & $.000^{\mathrm{a}}$ \\
\cline { 2 - 7 } & Residual & 1484.993 & 793 & 1.873 & & \\
\cline { 2 - 7 } & Total & 1688.122 & 802 & & & \\
\hline
\end{tabular}

Using the enter method it was found that the switch intention and predictors variable explain a significant amount of the variance $\left(F(9,793)=12.053, p<.001, R^{2}=.12, R^{2}\right.$ Adjusted $\left.=.110\right)$. 
Table 10: Coefficients.

\begin{tabular}{|l|c|c|c|c|c|}
\hline Model & \multicolumn{2}{|c|}{ Un-standardized Coefficients } & Standardized Coefficients & & \\
\hline & $\mathrm{B}$ & Std. Error & Beta & $\mathrm{T}$ & Sig. \\
\hline (Constant) & .075 & .405 & & .185 & .853 \\
\hline Age & .02 & .048 & .015 & .408 & .684 \\
\hline Occupation & .016 & .026 & .021 & .611 & .541 \\
\hline Income & .177 & .055 & .116 & 3.24 & .001 \\
\hline Education & .012 & .033 & .014 & .372 & .71 \\
\hline location of Stay & .163 & .068 & .085 & 2.408 & .016 \\
\hline Pre-paid or Post paid & -.054 & .188 & .01 & -0.287 & .774 \\
\hline How Long used & .084 & .032 & .096 & 2.598 & .01 \\
\hline Degree to which service met Expectation & .445 & .058 & .263 & 7.718 & .000 \\
\hline How many times switched in the past & .081 & .034 & .08 & 2.355 & .019 \\
\hline
\end{tabular}

The model indicates a significant relationship. The coefficients of Income $(p<.01)$, location of stay $(p<.05)$, how long used $(p<.05)$, degree to which services met expectation $(p<.001)$ and 'how many times switched in the past $(p<.05)$. Thus it can be argued that higher the income, longer the usage, and higher the ability of the product to meet expectation (quality) then there will be more probability of customer switching to competitors.

It could also indicate a case of 'over-choice' (Alvin Toffler in Future Shock, 1971) where in there could be a cognitive dissonance. The preconditions for 'over-choice' are also apparent in case of telecom industry when there is similar set of services from multiple set of competitors. When the number of choices is increased the satisfaction level increases however after a point it decreases indicating an inverted 'U' (Shah and Wolford, 2007).

\section{Conclusion}

External factors also impact the perception of quality. Quality is not always intrinsic to the product alone. It is a competitive concept. External factors increase or decrease the expectation from the product or services, thus the gap between expectation and service received would distinguish between good or bad quality. Such external factors would act as moderator.

Similarly very low switching cost and commoditization of the service would indicate very low distinction of quality perception about the services among customers. This could give rise to experimentation instinct and frequent switching. The frequent switching of service provider among a set of service providers would actually indicate a swinging rather than a permanent switch. This research indicates that the customers use a particular service provider as base and then switch the auxiliary service provider. Thus the challenge for service providers would be to entrench themselves as a base service provider.

The quality perception, past change behavior and future intent to switch were found to be significantly associated with age, location of stay and income. These factors were not significantly associated with gender. Education was not significantly associated with quality perception, where as it was associated with past change and future switch intention.

The longer the person uses a service provider and the intention to switch was found to be significantly associated. Thus in case of a natural progression of age, income and location of stay there will be pronounced intention to switch telecom service provider. In the current research, respondents have rated the ability of meeting the expectation at a higher level. This could indicate novelty seeking behavior of customers. Secondly, as we propose, it could also mean 'satiated customer'. Customer need is met beyond needs and product features overwhelm the customers. In such a scenario, customers would intend to switch even if satisfied.

\section{Scope for Further Study}

The behavioral aspect of switching could have more reasons than investigated in the current research. The switching could be related to events or changes associated with customer, it could be more induced as a group activity rather than a sole individual activity. Similarly it needs to be studied further if the customers are in a position to carry out a meaningful comparison of price points or qualitative aspect in a context of higher number of service providers and service parameters. Each telecom service provider is trying to find a niche segment and create appropriate plans; few of such plans are also event driven. So how does the customer really choose the service provider at the first place, and how do 
they decide to switch subsequently? Is it a planned activity with decision models or a casual, chance based activity? The switch indicates a chaotic pattern or there could be some trend?

One important aspect of switching intention is also about the number of competitors available. A consistent switch pattern among fixed number of service provider would actually mean a swinging intent rather than a complete switch intent, wherein the customer comes back in regular pattern. Similarly "differentiation" could be tested to be included as a dimension of service quality.

\section{References}

Bertrand, K. 1989. Putting customers first. Business Marketing 74 (December): 30-34.

Bolton, R. N., \& Drew, J. H. (1991). A multistage model of customers' assessments of service quality and value. Journal of consumer research, 375-384.

Brown SA, Gulycz M (2001). Customer relationship management: A strategic imperative in the world of e-business: New York: Wiley.

Chadha, S. K., \& Kapoor, D. (2009). Effect of switching cost, service quality and customer satisfaction on customer loyalty of cellular service providers in Indian market. IUP Journal of Marketing Management, 8(1), 23-37.

Chakravartya, S., Feinberga, R, Rheeb, E.Y, (2004). Relationships and individuals' bank switching behaviour, Journal of Economic Psychology, Volume 25, Issue 4, August 2004, Pages 507-527,doi:10.1016/S0167-4870(03)00051-5

Cronin, J. J. and Taylor, S. A., (1992), "Measuring Service Quality: A Reexamination and Extension", Journal of Marketing, Volume 56, Number 3, Pages 55-68, 1992.

Danaher, P. J., \& Rust, R. T. (1996). Determining the optimal return on investment for an advertising campaign. European Journal of Operational Research, 95(3), 511-521.

Danaher, P.J., and Mattsson, J., (1994) "Cumulative Encounter Satisfaction in the Hotel Conference Process", International Journal of Service Industry Management, Vol. 5 Iss: 4, pp.69 - 80

Danner, U. N., Aarts, H. and de Vries, N. K. (2008), Habit vs. intention in the prediction of future behaviour: The role of frequency, context stability and mental accessibility of past behaviour. British Journal of Social Psychology, 47: 245-265. doi: 10.1348/014 $466607 \times 230876$

Equity master report: https://www.equitymaster.com/research-it/sector-info/telecom/ Telecom-Sector-Analysis-Report.asp accessed on $3 / 7 / 2015$

Ewing, M.T., (2000). Brand and retailer loyalty: past behavior and future intentions, Journal of Product \& Brand Management, Vol. 9 Iss: 2, pp.120 - 127, DOI: dx.doi.org/10.1108/10610420010322161

Fornell, C. (1992). A national customer satisfaction barometer: the Swedish experience. the Journal of Marketing, 6-21.

Keaveney, S. M., (1995), Customer Switching Behavior in Service Industries: An Exploratory Study, Journal of Marketing, Vol. 59, No. 2 (Apr., 1995), pp. 71-82

Keaveney, S. M., and Parthasarathy, M. (2001). Customer switching behavior in online services: An exploratory study of the role of selected attitudinal, behavioral, and demographic factors, Journal of the Academy of Marketing Science, Fall 2001, Volume 29, Issue 4, pp 374-390

Kim, M. K., Park, M. C., \& Jeong, D. H. (2004). The effects of customer satisfaction and switching barrier on customer loyalty in Korean mobile telecommunication services. Telecommunications policy, 28(2), 145-159.

Lee, J., Lee, J., \& Feick, L. (2001). The impact of switching costs on the customer satisfaction-loyalty link: mobile phone service in France. Journal of services marketing, 15(1), 35-48.

Mazursky, D., Labarbera, P.. and Aiello, A., (1987). When consumers switch brands. Psychology \& Marketing, Volume 4, Issue 1, pages 17-30, Spring 1987, DOI: 10.1002/mar.4220040104

Mittal, B. and Lassar, W.M., (1998). Why do customers switch? The dynamics of satisfaction versus loyalty. Journal of Services Marketing, Vol. 12 Iss: 3, pp.177 - 194:

Monroe, K.B. (1991), Pricing - Making Profitable Decisions, McGraw-Hill, New York, NY

Morwitz, V., (1997), Why Consumers Don't Always Accurately Predict Their Own Future Behavior, Marketing Letters, January 1997, Volume 8, Issue 1, pp 57-70

Neal,W. D. (1999). Satisfaction is nice, but value drives loyalty. Marketing Research, 21-23

Oliver RL. Whence consumer loyalty? J Mark 1999;63:33 - 44 [October-Special Issue].

O'Neill, M., \& Palmer, A. (2003). An exploratory study of the effects of experience on consumer perceptions of the service quality construct. Managing Service Quality: An International Journal, 13(3), 187-196.

Ouellette, J.A. and Wood, W. (1998). Habit and intention in everyday life: The multiple processes by which past behavior predicts future behavior. Psychological Bulletin, Vol 124(1), Jul 1998, 54-74. http://dx.doi.org/10.1037/0033-2909.124.1.54

Parasuraman, A., \& Grewal, D. (2000). The impact of technology on the quality-value-loyalty chain: a research agenda. Journal of the academy of marketing science, 28(1), 168-174.

Ranaweera, C., \& Neely, A. (2003). Some moderating effects on the service quality-customer retention link. International journal of operations \& Production management, 23(2), 230-248.

Rapert, M., Wern, B. (1998). Service Quality as a Competitive Opportunity. The Journal of services Marketing, 12(3), 223-235.

Rust, R. T., \& Oliver, R. W. (1994). The death of advertising. Journal of Advertising, 23(4), 71-77. 
Sahoo, A. K., Kar, B., \& Das, S. (2015). Differentiated Service is the Success Measure: An investigation in Telecom Industry Odisha, India. Mediterranean Journal of Social Sciences, 6(4), 96.

Shah, A. M., \& Wolford, G. (2007). Buying behavior as a function of parametric variation of number of choices. Psychological Science, 18, 369-370. doi:10.1111/j.1467-9280.2007.01906.x

Sheeran, P., Orbell, S., Trafimow, D. (1999). Does the Temporal Stability of Behavioral Intentions Moderate Intention-Behavior and Past Behavior-Future Behavior Relations? Personality and Social Psychology Bulletine, June 1999 vol. 25 no. 6 724-734, doi: $10.1177 / 0146167299025006007$

Valentyna Melnyk, Stijn M.J. van Osselaer, Tammo H.A. Bijmolt (2009) Are Women More Loyal Customers Than Men? Gender Differences in Loyalty to Firms and Individual Service Providers. Journal of Marketing: July 2009, Vol. 73, No. 4, pp. 82-96.

Woodruff, R. B. (1997). Customer value:The next source of competitive advantage. Journal of the Academy of Marketing Science, 25, 139-153.

Zeithaml, V. A. (1988). Consumer perceptions of price, quality, and value: a means-end model and synthesis of evidence. The Journal of marketing, 2-22. 